\title{
The Practicality and Application of Aaker's Customer Based Brand Equity Model in the Nigerian Banking Sector
}

\author{
Talatu Raiya Umar, Nik Kamariah Nik Mat", Fatima Alfa Tahir, Jamal Mohammed Alekam
}

Othman Yeop Abdullah Graduate School of Business, Universiti Utara Malaysia, Sintok, 06010, Malaysia

\begin{abstract}
The study investigates the practicality and application of Aaker's customer based brand equity model in the Nigerian banking sector using 185 bank customers of Kano and Lagos branch offices of Guaranty Trust Bank in Nigeria. The exogenous variables are perceived quality as measured by 4 items, brand awareness by 3 items, brand association by 4 items, while the endogenous variables are brand loyalty by 4 items and brand equity by 3 items. The study is a quantitative research which sourced data through questionnaire. 250 questionnaires were administered to bank customers and 185 were returned representing 74 percent response rate. Structural Equation Modelling (SEM) was used to analyze the relationship among the variables. The goodness of fit indices of the revised model indicate adequate fit (GFI=.938, RMSEA=.039, RATIO $\mathrm{CMIN} / \mathrm{DF}=1.259$, $\mathrm{P}-\mathrm{VALUE}=.075$ ). The regression parameter estimates show three significant positive relationships between brand loyalty and brand association with brand equity $(\beta=.875, \mathrm{CR}=5.923, \mathrm{P}<.001)$; brand loyalty \& brand equity $(C . R=3.017, \beta=.453 \& P=.003)$ and brand association \& brand equity (C.R 2.280, $\beta=.520 \& P=.023)$. Future studies need to be done if the findings are to be generalized to other commercial and non commercial banking customers in the light of the significant cultural and religious differences across Nigeria. Further studies may also strengthen these findings by including organizational effectiveness into the model.
\end{abstract}

Keywords Brand Equity, Perceived Quality, Brand Awareness, Brand Association, Commercial Bank Customers, SEM

\section{Introduction}

Business environments over the years have increasingly recognized the significance of brand equity as a means of competitive advantage, which have consequently attracted scholarly interest in recent times. Brand equity has been described as value added or incremental utility enjoyed by a product because of its brand name[1]. High levels of brand equity are indications of customers' strong associations to the brand and their perceptions of its good quality which results in their continued loyalty to the brand[2]. Customer-based brand equity (CBBE) reflects the customer's perspective about their knowledge, association and familiarity with brand[3]. In the banking industry, brand equity has gained much prominence for sustained competitive advantage. As bank products become less standardized and similar, banks are focusing on improving and sustaining the values of their intangibles for competitive advantages[4]. This study contributes to the extant literature

* Corresponding author:

drnikuum@gmail.com (Nik Kamariah Nik Mat)

Published online at http://journal.sapub.org/economics

Copyright $@ 2012$ Scientific \& Academic Publishing. All Rights Reserved by empirically testing the applicability of the consumer based brand equity dimensions and their interaction within the Nigerian banking sector to inform deeper understanding of brand equity dimensions and how they are reflected in customer behavior.

\section{Research Problem}

The Nigerian banking sector is very important to the economy and recently underwent series of structural reforms in the wake of banking failures and the loss of confidence accompanying such failures. The first reform (bank consolidation) in 2005 saw the reduction in number of banks from 89 to 24 mega banks. By 2010, the Central bank had to bail out 10 commercial banks with N1.725 trillion Naira (about \$11.5billion) and hand over their ownership to Asset Management Company of Nigeria (AMCON). As a result, the remaining banks depend on the management of their 'worth' in the eyes of the customers for continuity and competitive advantage.

Past studies have examined the Aaker's brand equity model in studying consumer behavior in various industries $[3],[5],[6],[7]$. However, there is very little literature on the model's applicability in the banking sector sub-Saharan 
Africa, especially in Nigeria.

\section{Research Objectives}

The main objective of the study is to examine the practicality and application of Aaker's customer based brand equity model from the perspectives of Guaranty bank customers in Nigeria. To achieve this aim, the study seeks the following specific ob jectives:

1. To examine the extent to which perceived quality influences brand equity

2. To assess the extent to which brand association influences brand equity

3. To evaluate the extent to which brand awareness influences brand equity

4. To examine the extent to which brand loyalty influences brand equity

5. To evaluate the extent to which brand loyalty mediates the relationship between perceived quality, brand association, brand awareness and brand equity

\section{Literature Review}

\subsection{Perceived Quality and Brand Equity}

Perceived quality is a good determinant of brand loyalty and brand equity[8]. Perceived quality has been found to be significantly associated with brand equity in the tested model for hotels, among shopping mall consumers and students choice of USA products in India[8],[9],[2],[10],[11].

\subsection{Brand Association and Brand Equity}

Brand association has been found to have significant relationship with brand equity[8],[7],[10],[11].

\subsection{Brand Awareness and Brand Equity}

Literature has also given support for the relationship between brand awareness and brand equity[10],[11]. Reference[12] also found a partial support for brand awareness-equity relationship while[13] found a positive relationship.

\subsection{Brand Loyalty and Brand Equity}

Brand loyalty was reported has having a dominant influence on brand equity, brand association and brand awareness dimensions were not clearly dispersed, as in the previous studies[6],[8],[7],[10],[11].

\section{Research Hypothesis}

Based on the literature review, the study makes the following hypothesis:

Ho 1: Perceived quality has a significant positive effect on brand equity

Ho 2: Brand awareness has a positive significant direct effect on brand equity

Ho 3: Brand association has a significant direct ef-fect on brand equity

Ho 4: Brand loyalty has a significant direct effect on brand equity

\section{Research Methodology}

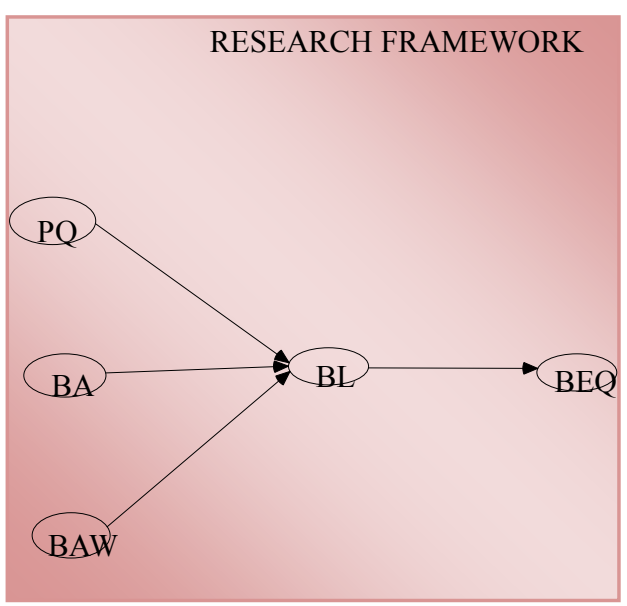

Figure 1. Research Framework

The research framework is based on Aaker's (1991) brand equity model (Figure 1).

\subsection{Sampling}

This study focused on customers of Guaranty Trust bank in Nigeria. Lagos and Kano state branches have been chosen as the sampling area because they represent the two most industrial and commercial centers in the country from the south and north respectively. A survey was carried out among the bank customers through self-administered questionnaires which were distributed to the customers of the selected banks using simple random sampling. Out of the 250 questionnaires issued out 185 representing $74 \%$ were filled and returned which were subsequently used for the analysis.

\subsection{Questionnaire Design}

In an attempt to increase content validity, the questionnaire was pretested in Kaduna state on a sample of 20 bank customers. The instrument consisted of items measuring the dimensions of brand equity and other demographic characteristics. The brand equity items were developed from existing scales to evaluate the five constructs on a 5 point likert scale (ranging from 1 as strongly disagree to 5 as strongly agree)

\subsection{Data Analysis}

A total of 250 questionnaires were issued to bank customers in lagos and kano, out of which 185 representing $74 \%$ were filled and returned which were subsequently used for the analysis. Structural Equation Modelling using Amos 16 was employed for confirmatory and path analysis. 
Measurement model and structural model were analyzed based on[14] and fit as suggested by[15].

\section{Research Findings}

The goodness of fit indices of the revised model indicate adequate fit (GFI=.938, RMSEA $=.039$, RATIO $\mathrm{CMIN} / \mathrm{DF}=1.259, \mathrm{P}-\mathrm{VALUE}=.075$ ) (Figure 2). Although seven hypotheses were proposed, the estimated model supported only three. Significant support was found for hypotheses $\mathrm{H} 3 \quad(\mathrm{~B}=.52, \mathrm{P}=.023, \mathrm{CR}=2.28), \mathrm{H} 4(\mathrm{~B}=.453$, $\mathrm{P}=.003, \mathrm{CR}=3.02$ ) and $\mathrm{H} 6$ (partial mediation).

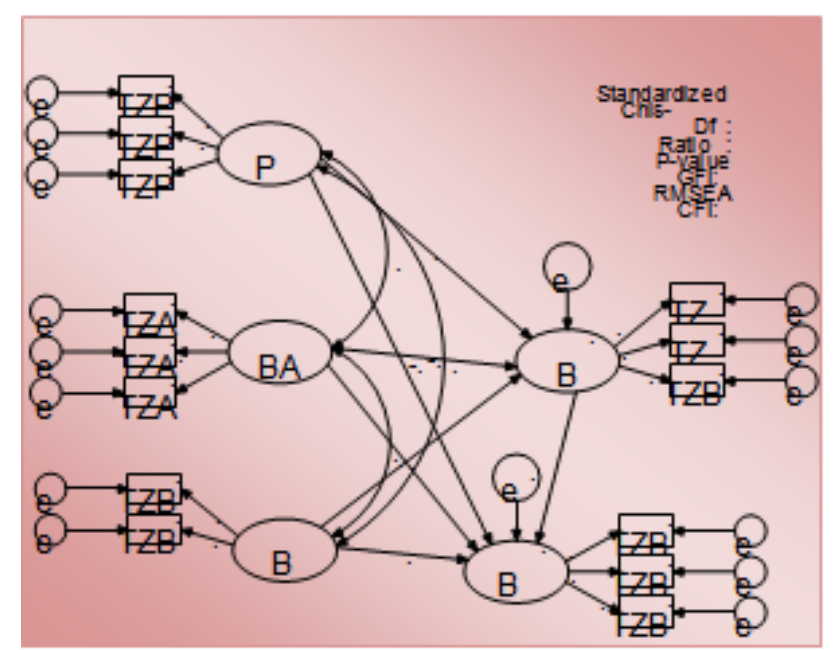

Figure 2. Revised Model

Table 1. Regression Weights

\begin{tabular}{|c|c|c|c|c|c|}
\hline & Estimate & S.E. & C.R. & P & Label \\
\hline BL-BA & .925 & .156 & 5.936 & $* * *$ & Par_13 \\
\hline BEQ-BL & .389 & .129 & 3.017 & .003 & Par_11 \\
\hline BEQ-BA & .471 & .205 & 2.299 & .021 & Par_14 \\
\hline
\end{tabular}

\section{Discussion Of Results}

The study examined the practicality and application of Aaker's customer based brand equity model in the Nigerian banking sector. Though the findings of this study do not entirely support Aaker's brand equity model, brand association and loyalty were found to exert significant influence on brand equity. This finding concurs with the findings of[7],[10],[13],[17]. Loyalty was also found to partially mediate the relationship between brand association and brand equity. This result also confirms the findings of [12][15]. These findings suggest that banks should manage strong and unique brand associations to engender favorable feelings and continued loyalty to products in order to sustain competitive advantages. The study did not find support for relationships between perceived quality and brand awareness with brand equity. This shows that quality and awareness of brand (bank) are not sufficient for creating and sustaining value added in banks.

\section{Conclusions And Future Research}

This study examined 3 exogenous and 2 exogenous variables. Though no significant relationship was found for perceived quality and brand awareness in relation to brand equity, brand loyalty was found to partially mediate the relationship between brand association and brand equity. Future studies need to be done if the findings are to be generalized to other commercial and non commercial banking customers in the light of the significant cultural and religious differences across Nigeria. Further studies may also strengthen these findings by including organizational effectiveness into the model.

\section{ACKNOWLEDGEMENTS}

We would like to thank Prof Dr. Nik Kamariah Nik Mat and Sukma Pea for their helpful comments and assistance on an earlier version of this paper.

\section{REFERENCES}

[1] Aaker, A. David,"Measuring Brand Equity across Products and Markets", Free Press, New York, NY, 1996.

[2] Kevin L. Keller,Strategic Brand Management: Building, Measuring and Managing Brand Equity, 2nd ed., Prentice-Hall, Englewood Cliffs, NJ.2003.

[3] Judith H.Washburn and Richard E. Plank, "Measuring brand equity: An evaluation of a consumer-based brand equity scale, Journal of Marketing Theory and Practice, vol.10, pp 46-62.

[4] Boonghee Yoo, Naveen Donthu and Sungho Lee, "An Examination of Selected Marketing Mix Elements and Brand Equity", Journal of the Academy of Marketing Science, no.2, vol 28, pp 195-212, 2000.

[5] Woo G. Kim and Hong-Bumm Kim, Measuring customer-based restaurant brand equity: Investigating the relationship between brand equity and firms' performance", Cornell Hotel and Restaurant Administration Quarterly, vol.45, pp 115-131, 2004.

[6] Atilgan Eda, Aksoy Safak and Akinci Serkan (2005), "Determinants of the brand equity: a verification approach in the beverage industry in Turkey", Marketing Intelligence \& Planning,vol. 23, pp. 237-248, 2005.

[7] Xiao Tong and Jana M. Hawley, "Measuring customer-based brand equity: empirical evidence from the sportswear market in China", Journal of Product \& Brand Management, no.4, vol.18, pp262-271, 2009.

[8] Rüc,han Kayaman and Huseyin Arasli,"Customer based brand equity: evidence from the hotel industry", Managing Service Quality,vol.17, pp 92-109, 2007.

[9] Sandra Maria C. Loureiro and Miranda J. Francisco, "Brand Equity and Brand Loyalty in the Internet Banking Context: FIMIX-PLS Market Segmentation", Journal of Service Science and Management, no.4, vol.4, pp 476-485, 2011. 
[10] Aaker A. David, "Managing Brand Equity. Measuring Brand Equity across Products and Markets", New York: Free Press, 1991.

[11] Ravi Pappu, Pascale G. Quester and Ray W. Cooksey, (2005). Consumer-based brand equity: improving the measurement - empirical evidence. Journal of Product \& Brand Management, no.3, vol.14, pp143-154, 2005.

[12] Hyun-Joo Lee,Archana Kumar andYoun-Kyung Kim, "Indian consumers' brand equity toward a US and local apparel brand", Journal of Fashion Marketing and Management, vol.14, pp 469-485, 2010

[13] Juntunen Mari; Juntunen Jouni and Juga Jari, “Corporate brand equity and loyalty in B2B markets:A study among logistics service purchasers", Journal of Brand Management ,vol.18, no.4, pp. 300-311,2011.

[14] Rosa E. Rios and Hernan E. Riquelme, "Brand equity for online companies", Marketing Intelligence and Planning, Vol. 26, no.7, pp. $719-742$, (2008).

[15] Juntunen Mari; Juntunen Jouni and Juga Jari, "Corporate brand equity and loyalty in B2B markets:A study among logistics service purchasers", Journal of Brand Management ,vol.18, no.4, pp. 300-311,2011.

[16] Anderson C. James and Gerbing W. David, "Structural equation modeling in practice: a review and recommended two-step approach", Psychological Bulletin, vol. 103, no.3, pp. 411-423, 1988.

[17] Ching-Fu Chen and Wen-Shiang Tseng, "Exploring Customer-based Airline Brand Equity: Evidence from Taiwan"Transportation Journal American Society of Transportation \& Logistics Inc,vol. 49, pp. 24-34, 2010.

[18] Hu Li-tze and Bentler M. Peter,"Cutoff criteria for fit indexes in covariance structure analysis: conventional criteria versus new alternatives", Structural Equation Modeling, vol. 6, pp. $1-55,1999$.

[19] Richard G. Netemeyer, Balaji Krishnan, Chris Pullig, Guangping Wang, Mehmet Yagci, Dwane Dean, Joe Ricks, and Ferdinand Wirth, "Developing and validating measures of facets of customer-based brand equity", Journal of Business Research, vol.57, pp 209-224, 2004. 